\title{
Nogi. Męskość i niepełnosprawność w Szpitalu Czerwonego Krzyża Michała Choromańskiego
}

\begin{abstract}
Galant Arleta, Nogi. Męskość i niepełnosprawność w Szpitalu Czerwonego Krzyża Michała Choromańskiego [Legs. Masculinity and disability in Michał Choromański's Szpital Czerwonego Krzyża (Red Cross Hospital)]. „Przestrzenie Teorii” 34. Poznań 2020, Adam Mickiewicz University Press, pp. 345-356. ISSN 1644-6763. DOI 10.14746/pt.2020.34.16.

In the article, the author presents an interpretation of the novel Szpital Czerwonego Krzyża by Michał Choromański. One of the key interpretative hypothesis advanced by the author of the article based on a reading of the novel is the assumption that the work constitutes an important statement on masculinity and disability, exposing the artificiality and unoriginality of masculine gender roles and criticizing somatic culture. This criticism is, in turn, significant with regard to twentieth-century reflections on body issues in post-war modernity. The author of the article indicates that Choromański's work, written before the Second World War but published not until 1956, is a piece of significance for the reconstruction of issues of disability in terms of Polish literary history.
\end{abstract}

KEYWORDS: Polish literature, Michał Choromański, masculinity, disability, body

Przyznajmy, że Szpital Czerwonego Krzyża Michała Choromańskiego nie należy do powieści wybitnych ${ }^{1}$. Jest to ksiażka przeciętna, w porównaniu do Zazdrości i medycyny - będącej zazwyczaj punktem odniesienia dla całej twórczości pisarza, stanowiącej dowód na to, że mógł on być w latach późniejszych autorem utworów znacznie lepszych i ciekawszych - Szpital... pozostaje opowieścia pod względem formalnym słabo wykoncypowaną, bardzo nierówna, kompozycyjnie niedopracowaną. Wspólny dla obu tekstów byłby mizoginiczny horyzont narracji, którego Choromański nie potrafił lub też nie chciał przekroczyć, kreując kobiece postaci². O ile jednak w debiutanckiej prozie był to horyzont zakreślony na szeroką skalę, skalę główna, w ramach której rozgrywały się wszystkie powieściowe konflikty i ujawniały męskie fantazmaty, o tyle w Szpitalu Czerwonego Krzyża kobieta wprowadza do powieści perwersję raczej na prawach koniecznego (!?)

${ }^{1}$ M. Choromański, Szpital Czerwonego Krzyża, Poznań 1987. Cytaty pochodzące z tego wydania oznaczam w tekście, przyjmując skrót SZ i podając numery stron.

${ }^{2}$ A. Kosińska, Literatura choromaniaków, „Dekada Literacka” 1997, nr 10-11; B. Umińska, Michat Choromański. Zazdrość i medycyna. Pornograficzna Rebeka, [w:] tejże, Postać z cieniem. Portrety Żydówek w polskiej literaturze, Warszawa 2001. 
suplementu ${ }^{3}$. Tym razem mamy bowiem do czynienia $\mathrm{z}$ historia przede wszystkim o mężczyznach wśród mężczyzn, co okazuje się niezaskakujące, albowiem proza autora Białych braci doczekała się literaturoznawczych analiz w kontekście ujętych w niej relacji męsko-męskich ${ }^{4}$. W moim przekonaniu zdaje się to dodatkowo istotne, aby zainicjować lekturę utworu Choromańskiego z zamiarem prześledzenia wątków dotyczących zarówno męskości, jak i niepełnosprawności.

Rzecz jasna, pojęcie niepełnosprawności nie jest pojęciem pochodzącym z porządku utworu, który został napisany jeszcze przed II wojną światowa. Właściwe dla międzywojennej prozy Nałkowskiej czy też Schulza określenie "kalectwo" też nie jest tu nadużywane. Owszem, jeden z pobocznych wątków powieści Choromańskiego powiela tę bardzo anachroniczną kliszę, na której obraz utraty fizycznej pełnosprawności, czy też może raczej wyobrażenie o tej utracie, przedstawia się niczym uzewnętrzniony emblemat wewnętrznego cierpienia jednej z bohaterek $^{5}$, lecz na szczęście odnajdziemy w Szpitalu Czerwonego Krzyża także inną historię. Spróbujmy ją tutaj zrekonstruować.

Akcja owej zapomnianej powieści Michała Choromańskiego rozgrywa się w przestrzeni szpitala znajdującego się w bliżej nieokreślonym, acz z cała pewnością niecentralnym, ulokowanym gdzieś na Podkarpaciu, polskim mieście/miasteczku6 ${ }^{6}$ Bohaterami utworu sa pacjenci męskiego oddziału placówki oraz opiekujący się nimi lekarze. Piszę „opiekujący się”, a nie „leczący" nie przez przypadek. Jedno z głównych powieściowych napięć między pacjentami a medykami polega bowiem na tym, że większość „lokatorów”

${ }^{3} \mathrm{~W}$ drugiej części powieści pojawia się epizodyczna postać mecenasowej, żony jednego z pacjentów, która podczas wizyt w szpitalu odkrywa w sobie przyjemność patrzenia na ciepiących chorych.

${ }^{4}$ W. Śmieja, Erotyzacja relacji męsko-męskich w prozie Michała Chromańskiego, [w:] tegoż, Homoseksualność i polska nowoczesność. Szkice o teorii, historii i literaturze, Katowice 2015, s. 350-377. W. Śmieja, Dygresje na temat kampowania męskości. O Dygresjach na temat kaloszy Michała Choromańskiego, [w:] (Nie)męskość w tekstach kultury XIX i XX wieku, red. B. Zwolińska i K.M. Tomala, Gdańsk 2019. P. Sobolczyk, Homogotycki skandal wedtug Choromańskiego, „Czytanie Literatury: Łódzkie Studia Literaturoznawcze” 2014, nr 3, s. 239-262.

${ }^{5}$ „Wydawało się jej, że rozumie człowieka, któremu amputowano nogę, że w ogóle rozumie kalectwo, ponieważ w duszy uważała się za kalekę. Były po temu dwie przyczyny. Pierwsza, że kilka lat temu, będąc jeszcze słuchaczka polonistyki, pokochała mężczyznę i nie doznała żadnej przyjemności, kiedy mu się oddała. Druga: że od kilku lat mimo młodego wieku czuła, że się starzeje" (SZ, 72).

${ }^{6}$,Jednakże z dodatkowych informacji zawartych w tekstach, jak i z wypowiedzi pisarza wynika, że pierwowzorem miasta będącego pierwowzorem akcji obu utworów [chodzi także o miasto w Zazdrości i medycynie - przyp. A.G.] jest Zakopane. Choromański przebywał tam na leczeniu w dwóch placówkach. Sanatorium Bratniej Pomocy i Sanatorium Polskiego Czerwonego Krzyża”. J. Januk, Terminologia i problematyka medyczna we wczesnych (1931-1939) utworach Michała Choromańskiego, „Medycyna Nowożytna” 2005, 12/1-2, s. 21. 
szpitalnych łóżek to gruźlicy-chronicy, których ozdrowienie nie jest możliwe, co z kolei dla młodych ambitnych asystentów bywa źródłem frustracji, a niekiedy nawet poczucia daremności podejmowania decyzji o jakichkolwiek medycznych interwencjach. Wszyscy próbują się mierzyć z nieskutecznością kuracji oraz z potencjalną niepełnosprawnością mężczyzn spustoszonych przewlekłymi niedyspozycjami.

Opisywany fragment szpitalnego życia ma charakter odpadowy, resztkowy. Przedstawionym w utworze zdarzeniom i „działaniom” poszczególnych postaci odpowiadaja rozpoznawalne, charakterystyczne dla prozy Choromańskiego właściwości. „Łasicz, Reinhort, Waszczak, Dracz to ludzie - zauważa badaczka ${ }^{7}$ - cierpiący na rozmaite choroby, ale niewiele lub w ogóle nic nie wiemy o ich przeżyciach pozaszpitalnych. [...] Narratora obchodza jedynie same przeżycia i zjawiska w psychice [...]".

W przypadku Szpitala Czerwonego Krzyża owe przeżycia i zjawiska dotyczą sposobów przeżywania bólu, znoszenia lub też przeczekiwania cierpienia i stwarzania pozorów wytrzymałości. Na inny równie ważny temat powieści składają się - to także zazwyczaj istotne zwłaszcza w przedwojennych tekstach autora Opowiadań wariackich - wybory i postępowanie medyków, które umożliwiaja pisarzowi pośrednio sformułować pytania o władzę medycyny oraz etyczne lub wątpliwie etyczne postawy praktykujących ją przedstawicieli. Na przecięciu dwu światów - świata lekarzy i świata pacjentów Choromański w konwencji sensacyjnej zbudował jeden z wątków, któremu warto poświęcić więcej uwagi.

Interesująca jest bowiem ta tajemnicza, chwilami bardzo osobliwa, celowo przez narratora do końca nieobjaśniona relacja między podporucznikiem Łasiczem, „pacjentem numer cztery”, a młodym ambitnym asystentem Chwacińskim. Wyłącznie na początku powieści zdaje się ona szczególna, pierwszoplanowa, w dalszych partiach Szpitala... zostaje rozmyta, jakby Choromański nie miał pomysłu na jej rozwiązanie albo traktował ja jako okazję do stworzenia kryminalno-aferalnego epizodu dla doraźnej tylko intrygi. Niezależnie od tego, czy mamy do czynienia z niezaplanowanym niedopracowanym pomysłem pisarskim, czy też z celowo niespełniona pisarską obietnicą sensacji, stosunek Łasicza do Chwacińskiego i Chwacińskiego do Łasicza wiele tu znaczy.

Cóż zaskakującego w tym, że asystent - wykonawca zabiegu amputacji nogi podporucznika - unika pacjenta, wymawia się z obchodu pod pretekstem troski o jego psychiczną kondycję, że nie chce rozmawiać z człowiekiem bez kończyny, o której braku zdecydował? Przełożony chirurga rozumie tę

${ }^{7}$ S. Wysłouch, Twórczość Choromańskiego wobec międzywojennego psychologizmu, „Pamiętnik Literacki" 1975, 66/1, s. 78. 
postawę, my czytelniczki/czytelnicy też możemy spróbować ją zrozumieć, narrator dobitnie wskazuje, że Łasicz leży zdruzgotany rezultatem operacji, jego prawa noga zaś od czterech dni „spoczywa w ogrodzie pod krzakiem bzu, za murem kostnicy".

Ów szczegół - noga zakopana w ogrodzie, jest makabryczny, lecz i możliwy w pozapowieściowym świecie. Ustawy z lat trzydziestych o postępowaniu z ciałami zmarłych zawierały wytyczne dotyczace zwłok i martwych szczątków, ale nie regulowały w żaden sposób obchodzenia się ze szczątkami osób żyjących ${ }^{9}$. Nie chodzi teraz jednak o ustalanie prawdopodobieństwa. Idzie o to, że Choromański z cała pewnością podsuwa nam tą zakopaną noga czytelną figurę utraty, którą zgodnie z freudowską wykładnią skojarzyć należałoby z figura kastracji. Byłoby to skojarzenie potwierdzone i dopełnione snami hospitalizowanego bohatera, które narrator opowiada gęsto - snami o fizycznej nadsprawności, o jeżdżeniu na nartach, wspinaniu się, pływaniu. Wprawdzie w sprawie nóg Freud więcej uwagi poświęcił kobietom i zjawisko seksualizacji kończyn dolnych powiązał z teorią fetyszyzmu ${ }^{10}$, ale po lekturze Schodami w górę, schodami w dót ${ }^{11}$, gdzie kobiece łydki okazują się wymownym erotycznym wabikiem, wolno przypuszczać, że Choromański zakopał nogę podporucznika z niejaka - po freudowsku obmyśloną - premedytacją $^{12}$.

${ }^{8}$ „Łasicz spał, śniło mu się znowu, że jedzie na nartach. Śnieg był puszysty [...]. Wiatr osmalił mu twarz, potem cisną go do jakiejś białej przepaści. [...] Lecz smak anegdoty polegał na tym, że właściwie wyrżną rzeczą nie istniejąca, albowiem prawa noga porucznika od czterech dni już spoczywała w ogrodzie pod krzakiem bzu, za murem kostnicy" (SZ, 18).

9 „Ustawy [z 1932 i 1934 roku - przyp. A.G.] zawierały uregulowania dotyczące pochówku zwłok i ich szczątków, nie wspominały natomiast w ogóle o szczątkach pochodzących od osób żyjących. Żadnych uregulowań w tym zakresie nie zawierały też ustawowe przepisy sanitarne, ani ustawy o zakładach opieki zdrowotnej. Być może stosowne zapisy istniały w rozporządzeniach wykonawczych, do których jednak autorowi nie udało się dotrzeć. Można wszakże zaryzykować opinię, że opisane przez Choromańskiego postępowanie było zgodne z ówczesną praktyką. Odpady medyczne spalano w szpitalnej kotłowni (z opisu Szpitala Czerwonego Krzyża wiemy, że kotłownię posiadał), zapewne też utylizowano w ten sposób szczątki ludzkie. Za wyjątkiem tych, których gabaryty, jak w przypadku amputowanej na udzie kończyny, wymuszały szukanie innych rozwiązań”. J. Januk, dz. cyt., s. 30.

${ }^{10}$ Ch. de Brosses, O kulcie fetyszów, przeł. M. Skrzypek, Warszawa 1992, s. 29.

${ }^{11}$ M. Choromański, Schodami w górę, schodami w dót, Warszawa 2017.

${ }^{12}$ Motywy pogrzebanej nogi i tajemniczego „konfliktu” między lekarzem i pacjentem w powieści Choromańskiego należy odnieść do często przez pisarza wyzyskiwanego repertuaru znanego z konwencji gotyckiej. Warto podkreślić, że gotyckie aluzje nie służą tutaj podtrzymywaniu homoseksualnch/homofobicznych sekretów męskości. Gotycyzm w twórczości autora Zazdrości i medycyny - pisze o tym Piotr Sobolczyk (Por. P. Sobolczyk, dz. cyt.). - nie wyznacza specyficznego sposobu wypowiedzi o homoseksualności, raczej znacząco profiluje jego opowieści o męskich relacjach homospołecznych. Relacje te są strukturyzowane nie tylko przez homofobię. W Szpitalu Czerwonego Krzyża równie ważnym warunkiem męskości okazuje się lęk przed niesprawnością/porażka. 
Łasicz śni o posiadaniu nogi, śniąc zarazem swoje fantomowe bóle. Nie bez znaczenia jest fakt, że owe sny wywołuje i modeluje morfina, jesteśmy w rzeczywistości, w której nie ma mowy o instytucjonalnym terapeutycznym wsparciu, w Szpitalu... nie obowiązuja ani protezy fizyczne, ani psychiczne. Terapeutyzowanie i protetyzowanie w Polsce zostaną ważnymi, znacznie bardziej powszechnymi punktami programów kuracji dopiero po II wojnie światowej, wymuszą to doświadczenia wojennego inwalidztwa. Po 1945 roku zmienia się również nastawienie do niepełnosprawności związanej z przebytą chorobą gruźlicy ${ }^{13}$. Tymczasem Michał Choromański w Szpitalu Czerwonego Krzyża postrzega męski oddział, w którym rezyduja chorzy, niczym przestrzeń autarkiczną funkcjonujaca na rzecz pogłębiania szpitalnej alienacji. Sądzę, że można nawet odczytać ten utwór w schemacie opowieści o niejawnie sadystycznym modelu opieki. Narzędzia tortur nie sa wyrafinowane, w przypadku pacjenta po amputacji wystarczą na przykład buty:

Dracz spostrzegł koło szafy na podłodze lakierowane buty Łasicza. Pokręcił głowa „Strojniś". Buty w istocie były wspaniałe. I oto Draczowi przypomniała się rzecz dziwna: buty stoja już od czterech dni, nikt dotąd faktu tego należycie nie ocenił. Przeciwnie, głupi sanitariusz, porządkujac salę, obchodził się z nimi jak z cackiem. $\mathrm{Z}$ podwójnym szacunkiem ścierał kurz i stawiał je z powrotem między zlewem a szafa (SZ, 22).

Skuteczniejszymi „rekwizytami” pomocnymi w umacnianiu kuracjuszy w ich cierpieniu pozostają oczywiście afekty i emocje. Dlatego też znajdziemy w powieści kilka hipotez dotyczących tego, co zaszło między lekarzem a podporucznikiem. Chwaciński miał amputować nogę Łasicza pod nieobecność chirurga, bez którego zgody nie powinien był operować? To prawda, ale ostatecznie decyzja Chwacińskiego spotyka się z uznaniem szefa. Miałby też asystent pracować pod wpływem alkoholu? To nie zostaje potwierdzone, dowiadujemy się jedynie, że feralnego dnia „czuł się nieszczególnie”. W końcu okazuje się, że energię dziwacznej gry uników młodego doktora wobec beznogiego pacjenta zasila obrzydzenie. Dlaczego Łasicz jest Chwacińskiemu wstrętny? Być może dlatego, że lekarz bezwarunkowo przyjął na siebie powinności zajmowania się chorymi bez drastycznych zaniedbań i porażek, trudno zatem pogodzić mu się z faktem, że uczynił Łasicza nienaprawialnym, wadliwym. A więc byłaby to kwestia ambicji?

Jednocześnie narrator powieści we wcale nieprzesadnych aluzjach daje do zrozumienia, że poza szerszym kontekstem biopolitycznym, na którego tle niepełnosprawność podporucznika jest systemowym błędem - jego życie

${ }^{13}$ S. Kołos, Od gruźlicy do elektrycznego oka. Medycyna, niepetnosprawność i technologia w Polskiej Kronice Filmowej, „Kultura Współczesna” 2018, nr 3, s. 91-97. 
będzie bowiem prawdopodobnie polegało na bezterminowym zajmowaniu szpitalnego łóżka i nie przestanie być dowodem na brak absolutnej władzy medycyny nad choroba - zagadkowy „konflikt” Chwacińskiego i Łasicza dotyka ich męskich jednostkowych ucieleśnień, nagle kłopotliwych. Oczywiście nie mam na myśli kłopotliwości unieważniającej, bagatelizującej traumę Łasicza. Zwracam uwagę na to, że opowieść o traumatycznym doświadczeniu pacjenta zostaje przez Choromańskiego spleciona z interesujacymi i zaskakującymi wizjami ciała, dającymi się jak sądzę zrekonstruować wówczas, gdy zechcemy przyjrzeć się bliżej powieściowym demaskacjom, za sprawą których pisarz określa cielesne granice obu bohaterów.

To, co swoja powieścia polski pisarz mówi o męskim ciele, nazywam nie tylko interesującym, ale także zaskakującym, ponieważ obserwacje Choromańskiego wydają się zbieżne z krytyką kultury somatycznej, zaproponowana przez Adorna i Horkheimera w powojennych latach czterdziestych, a więc kilka lat po powstaniu Szpitala Czerwonego Krzyż $a^{14}$. Autor miał dobre intuicje i okazał się uważnym obserwatorem epoki, celnie bowiem uwyraźnił konsekwencje myślenia o męskim ciele na prezentystycznych, przedstawieniowych warunkach.

Każda próba, by 'doprowadzić do odrodzenia ciała', musi ponieść porażkę, ponieważ implicite wzmacnia ona istniejące w naszej kulturze 'rozróżnienie na ciało i ducha'. Jako obiekt troski ciało jest eksterioryzowane za pomoca przedstawień jako zwykły przedmiot materialny [...]. Zainteresowanie ciałem oznacza zatem zawsze wyalienow ane zainteresowanie zewnętrznym przedstawieniem znajdujacym się poza naszym duchowym Ja. [...] Entuzjaści cielesnego piękna [...] są złowieszczo powiązani z faszystowskimi eksterminatorami, którzy traktują ludzkie ciało [...] jako podatne mechaniczne narzędzie, którego części muszą zostać ukształtowane tak, by sprawnie służyły kontrolującej je władzy ${ }^{15}$.

Przypomniane przez Richarda Shustermana najważniejsze „cielesne” diagnozy niemieckich filozofów - diagnozy, zaznaczmy, których sam Shusterman nie podziela, ponieważ w jego przekonaniu wynikająca z nich krytyka kultury somatycznej zawiera uproszczoną wizję ciała przeciwstawionemu duchowi ${ }^{16}$ - pozwalają rozwinąć lekturę „cielesnych” wątków w powieści Choromańskiego we właściwych kierunkach. Tak oto podporucznik postrzega jednego z sanitariuszy:

${ }^{14}$ Myślę o tezach zawartych w opublikowanej w 1947 roku Dialektyce oświecenia. M. Horkheimer, T. Adorno, Dialektyka oświecenia. Fragmenty filozoficzne, przeł. M. Łukasiewicz, Warszawa 1994. Szpital Czerwonego Krzyża powstał przed wojna, jednak po raz pierwszy w całości został opublikowany dopiero w 1956 roku.

${ }^{15}$ R. Shusterman, Świadomość ciała. Dociekania z zakresu somaestetyki, przeł. W. Małecki, S. Stankiewicz, Kraków 2008, s. 49-50.

${ }^{16}$ Tamże, s. 51. 
Natychmiast z odrażająca szybkością przypomniał sobie wszystko. Była już pora obiadowa, chorzy jedli zupę. [...] Starał się nie patrzeć na sanitariusza wnoszącego basen. Sposób, w jaki ten się poruszał, jak się kołysał w biodrach, jak podburzająco zgrabnie zginał nogi w kolanach, wydał się Łasiczowi obelżywy i nienawistny (SZ, 19).

Niby to oczywiste, że w jednonogim bohaterze gapienie się (używam tego określenia za Rosemarie Garland-Thomson ${ }^{17}$ ) na zgrabnie zginającego nogi pielęgniarza wzbudza złe emocje. Rzecz jednak nie w samym chodzeniu, lecz w tym - podkreślmy - że jest ono nie dość właściwe, nie dość stosowne. Sanitariusz psuje chodzenie, degeneruje chodzenie, które dla - byłego wprawdzie, ale dobrze osadzonego w swojej roli - żołnierza jest przede wszystkim ruchem, ruchem, nie tańcem, nie kołysaniem się. Jest mechanika ciała (o czym w powieści powiadamiają senno-morfiniczne autowizualizacje Łasicza), nie zaś jego możliwą wariacją.

W Szpitalu... odnajdziemy jeszcze inną znacząca scenę gapienia się, poświadczająca, że Choromański podejmuje temat męskości, ciała i niepełnosprawności, drążąc stany fundamentalne:

Z cichym poświstem wtoczył się biały wózek, na wózku pod prześcieradłem leżał kadłub kolejarza, któremu lokomotywa ucięła obie nogi [...]. Sanitariusz chwycił kolejarza pod pachy, siostry za pośladki i kadłub przeniesiono na łóżko. Wówczas chory podporucznik po raz pierwszy od osiemdziesięciu czterech godzin podparł się łokciami i na wpół usiadł. Natychmiast pochwycił zbolałe, czarne spojrzenie, dwie nieprzytomne jamy oczu, tragarz patrzył na niego zajęczym wzrokiem bez powiek. Łasicz niespokojnie potrząsną głowa, ale oderwać się nie zdołał, patrzył również. Miał takie wrażenie, że tamten włazi mu przez oczodoły do samej głębi. [...] Łasiczowi wydawało się, że wszystko zastygło w oczekiwaniu. Podniósł rękę i poklepał po kocu, tak że uwidoczniła się ohydna pustka. Nie odrywając oczu, chciał coś powiedzieć i wyjaśnić, ale już [...] teraz tragarz tym samym wzrokiem patrzył na lampę w górze (SZ, 23).

Jeśli ktoś, tak jak Łasicz, myśląc ciało, myśli o normatywnych zewnętrznych dyspozycjach, to znaczy, że w ogóle nie myśli o ciele, które zawsze jednocześnie - jak konsekwentnie i dobitnie podkreślają badacze-somaestetycy z Shustermanem na czele ${ }^{18}$ - pozostaje ciałem psychicznym, duchowym, wewnętrznie przeżywalnym. Trauma bohatera Szpitala Czerwonego Krzyża nie wynika wyłącznie z utraty, traumatyczna zdaje się również nagła świadomość własnego ucieleśnienia, poczucie posiadania ciała, które przestaje być niewidoczne.

${ }^{17}$ R. Garland-Thomson, Gapienie się, czyli o tym, jak patrzymy i jak pokazujemy siebie innym, przeł. K. Ojrzyńska, „Czas Kultury” 2019, nr 4, s. 73-81.

${ }^{18}$ R. Shusterman, dz. cyt. 
Przypomnijmy rozpoznanie badaczki, analizującej intencje i skutki gapienia się na nietypowe ciała:

Wyparcie śmierci i słabości, które pozwala naszemu ego radzić sobie w życiu codziennym, wiąże się z tym, że nasze ciała pozostają dla nas niewidzialne. [...] Ciało, które przyciaga spojrzenie innych, wciaga naszą uwagę w zasadzkę, domagając się od nas uznania zarówno jego, jak i własnego ucieleśnienia. Tego rodzaju świadomość podważa oczywistość naszych własnych ciał, uzmysławiając nam to, że ciało bez przerwy podlega zaburzeniom wywołanym przez pragnienia, choroby i śmierć ${ }^{19}$.

Powiążmy to rozpoznanie z zacytowanym powyżej fragmentem powieści i uwzględnijmy raz jeszcze fakt, że Łasicz, tkwiąc w żołnierskich wyobrażeniach siebie/o sobie, doświadczać może wstrząsu - dotąd wyalienowana za sprawą militarnie wymodelowanych wizualizacji rzecz staje się ciałem i to ciałem, podkreślmy koniecznie, niepełnosprawnym bez bohaterskiego kontekstu. Choromański pozostaje dla Łasicza bezlitosny - nie dość, że nie obsadza podporucznika w roli wojennego inwalidy, to jeszcze sugeruje, że jego służba w wojsku zakończyła się w trybie dyscyplinarnym ${ }^{20}$. O tym, że autor Szpitala... odmawia swojemu bohaterowi wszelkich protez (z premedytacja podobną tej, z którą zakopał jego nogę w ogrodzie), przekonuje i ta krwawa, na poły burleskowa ${ }^{21}$ - scena powieści, w której Łasicz decyduje się heroicznie pomóc innemu pacjentowi:

Podporucznik Łasicz tymczasem skakał na jednej nodze, kikut huśtał się, a pusta pasiasta nogawica wlokła się po podłodze. W kącie między szafą a zlewem było kłębowisko ciał, młokos borykał się z Antonim Draczem, skrwawiony bandaż zwisał już w strzępach, podporucznik doskoczył na jednej nodze, chciał obezwładnić młokosa, ale poślizgnął się i wyrżnął kikutem w metalową poręcz jakiegoś łóżka (SZ, 181).

Jedna noga zostaje sprowadzona do jednej nogi, kikut do kikuta. Uzmysłowienie podporucznikowi faktu, że w ogóle ma on ciało przez obdarzenie go doświadczeniem niepełnosprawności nie należy być może do bardzo wyrafinowanych powieściowych rozwiązań, mimo wszystko ułatwia pisarzowi ukazanie „konfliktu” pacjenta i lekarza w dynamice znaczącego „konfliktu” ciał, męskich ciał.

Chwaciński skrywa bowiem swoją fizyczność pod lekarskim chałatem, trwa w przeświadczeniu, że emanuje lekarską dostojnościa, medyczną wła-

${ }^{19}$ R. Garland-Thomson, dz. cyt., s. 80.

${ }^{20}$ „Leżący o dwa łóżka od Dracza chory numer czwarty, Władysław Łasicz, był podporucznikiem rezerwy. Zachował o wojsku wspomnienia najlepsze, ale nie wzajemne, gdyż usunięto go stamtąd po dyscyplinarce" (SZ, 18).

${ }^{21} \mathrm{O}$ tym, że w całej twórczości Choromańskiego odnajdziemy znacznie więcej burleskowych fragmentów, pisze W. Śmieja, Dygresje na temat kampowania męskości... 
dzą triumfująca bezcielesnością. Jego fantazje zostają zniweczone co najmniej dwoma odnarratorskimi spojrzeniami. Pierwsze z nich:

W apteczce stał Chwaciński i drapał się w podbródek. Kitel lekarski był rozpięty od góry do dołu, widać było granatową kamizelkę maskująca kurzą pierś i granatowe spodnie wypchane na kolanach (SZ, 59).

I drugie:

Obaj szli od drzwi do drzwi, krokiem szybkim i równym, można powiedzieć: w takcie czterech czwartych z uderzeniem na raz i na trzy. Brieg trzymał lewą rękę w kieszeni, prawa chwytał za klamki. Opięty chałatem brzuch nie tylko mu nie ciążył, ale zdawało się, ułatwiał poruszenia. [...] Dotrzymujący mu kroku Chwaciński skrzyżował ręce na piersi wyniośle i opryskliwie, ale białe poły plątały mu się między nogami wcale nie po bohatersku (SZ, 33).

Czy to możliwe, że Choromański napisał powieść o skandalu męskiej cielesności? Tak, to bardzo możliwe. Amputując Łasiczowi nogę, Chwaciński pojął rzecz prostą i niewiarygodnie trudną zarazem, pojął mianowicie, że ciało jest ciałem. Co więcej, nie wiadomo, co to właściwie znaczy, bo konstruująca ciała obu mężczyzn militarno-medyczna wyobrażeniowa machina zacina się w obliczu doświadczenia niepełnosprawności. Gesty, role i zachowania dotychczas performatywnie ustanawiajace sprawna, kompletna, normatywną męskość okazuja się nieaktualne i bezużyteczne ${ }^{22}$.

Beznogi pacjent słusznie roi, że ma haka na chirurga, któremu ,ambicja i pewność siebie wyprężaja grzbiet" (SZ, 171). Łasicza uspokaja mianowicie jakieś „rozkoszne w swej podłości wspomnienie” (SZ, 137), prawdopodobnie „przechowywane przez asystenta w pamięci z taką samą dyskrecja”" (SZ, 137). Choromański inaczej niż w Zazdrości i medycynie nie dopowiada zdarzeń z sali operacyjnej. Co znamienne, w Szpitalu Czerwonego Krzyża męsko-męskie fantazmaty nie mają zresztą - w odróżnieniu od trójkątnej kobieco-męskiej konstelacji opisanej w debiutanckim utworze autora - fizjologicznych umocowań. W pierwszej powieści droga do rozwikłania tajemnicy prowadziła przez jajniki i flaki Rebeki, w drugiej na trop tajemnicy wskazuje zaledwie śmieszno-tragiczny kikut podporucznika ${ }^{23}$. Niemniej na tym tle absurdalność zachowania Chwacińskiego wypada z należytą przesadą - otrzymujemy sygnał, że gra toczy się o więcej niż nieprofesjonalne zachowanie lekarza odbierającego pacjentowi nogę, o więcej niż klęskę ambicji, a nawet o więcej niż klęskę medycyny i jej normalizacyjnych zadań. Jednonogi Łasicz jest istotnie „błędem systemu”, ale w kontekście szerszym, choć jednocześnie dla młodego lekarza w kontekście dużo bardziej osobistym; jest „błędem cielesnym”, natar-

${ }^{22}$ Nawiąuję do koncepcji performatywności płci J. Butler, Uwikłani w płeć. Feminizm i polityka tożsamości, Warszawa 2008.

${ }^{23} \mathrm{O}$ tajemnicy zaklętej w jajnikach Rebeki pisze trafnie B. Umińska, dz. cyt., s. 248-256. 
czywie dowodzącym istnienie - parafrazując Butler - męskości potencjalnie fałszywie zacytowanej, źle powtórzonej, niewłaściwie znaturalizowanej ${ }^{24}$.

Chirurg i pacjent nie moga się spotkać także dlatego, że Choromański wyprowadza ich obu z ról ofiary i bohatera, przegranego i zwycięzcy, obu postaciom brakuje sił, fizycznych i symbolicznych, na zawiązanie relacji poza schematami, poza opozycjami, odpowiadajacymi ich instytucjonalnym wcieleniom. Zdarza się, że Łasiczowi przez chwilę sensowna wydaje się analogia między obowiązkiem żołnierza i lekarza ${ }^{25}$. Myśl tę podporucznik szybko porzuca, uznając ją za nazbyt samolubna, łatwo usprawiedliwiająca zadawanie śmierci na polu bitwy. To interesujące, ale i przecież zupełnie zrozumiałe, że im dłużej Łasicz pozostaje pod wpływem morfiny, tym częściej traktuje spawy „miękko”, pokojowo. Warto dopowiedzieć, że ze stanem morfinicznym bohatera utworu Choromańskiego łączy się jeden z innych wyraźnie ambiwalentnych wątków powieści.

Otóż kiedy Łasicz z przyjemnością odkrywa, że z towarzyszem z sąsiedniej szpitalnej pryczy bardzo lubi rozmawiać o rybach (,ryby bowiem nie mają nóg, tylko płetwy", SZ, 24) i o skrzypcach (,skrzypce również nie mają dolnych kończyn, tylko szyję", SZ, 24), to moglibyśmy wyposażeni w wiedzę, płynącą dziś obficie z teorii posthumanistycznych ${ }^{26}$, pomylić narkotyczną ulgę odczuwaną przez pacjenta z wyzwolicielską wizją wspólnoty w materii. Brak nóg to problem w świecie ludzkim i właściwie tylko ludzkim, w obrębie naturokultury ${ }^{27}$ kwestia sprawności czy doskonałości jako zjawisk najwyższej wagi zostaje radykalnie zakwestionowana. Choromański nie o tym jednak napisał powieśće ${ }^{8}$.

${ }^{24}$ Judith Butler pisząc o tym, że gwarancją poprawnego odegrania płci kulturowej jest bezustanne odtwarzanie jej „oryginalnego" i „naturalnego” statusu, zwraca uwagę na to, iż każdy błąd, każda usterka w tej serii odtworzeń stanowi zarazem dowód na istnienie płci jako tożsamościowego ideału. Każdy błąd, każda usterka w odgrywaniu płci podważa tego ideału „oryginalność” i „naturalność”. J. Butler, dz. cyt.

${ }^{25}$ „Przypadkowo i niespodziewanie przyszła mu do głowy myśl: 'Lekarz też spełnia swój obowiązek'. Podobne twierdzenie było mu obce. Ba! Niebezpieczne do tego stopnia, że nie chciał przyznać się do jego autorstwa [...]. W popłochu samozachowawczym zaczął na gwałt szukać usprawiedliwiającego wytłumaczenia. Wreszcie wybrał jedno, które wydało mu się najlepsze. A to takie: 'Myśl o lekarzu przyszła ci do głowy tylko po to, ażeby rozgrzeszyć samego siebie za wepchnięty w gardło bagnet!"' (SZ, 155-156).

${ }^{26}$ Współczesne badania o niepełnosprawności bardzo często odwołują się do ustaleń z obszaru posthumanizmu. Zob. A. Galant, Kobiecość i niepetnosprawność. Między feminizmem a posthumanizmem, [w:] Nowa Kobieta - figury i figuracje, red. I. Iwasiów, A. Krukowska, A. Zawiszewska, Szczecin 2017.

${ }^{27}$ Jest to termin zaproponowany przez Donnę Haraway. Zob. np. tejże, Manifest gatunków stowarzyszonych, przeł. J. Bednarek, [w:] Teorie wywrotowe, red. A. Gajewska, Poznań 2012.

${ }^{28}$ Ów trop warto odnotować, ponieważ umożliwia on wskazanie istotnych granic myślenia Choromańskiego o ciele. Narracja autora Szpitala Czerwonego Krzyża zdaje się przekra- 
Ryby i skrzypce to tutaj raczej powieściowe narzędzia, spełniające funkcję reifikująca rozpacz i ból bohatera. Dodajmy, że funkcję znaną z kart międzywojennych dokonań literackich, powiązaną nierzadko z katastroficznymi refleksjami o nowoczesności, zazwyczaj jednak niezbieżną z najbardziej współczesnymi wyobrażeniami o ontologicznych związkach ludzi, zwierząt i rzeczy. Ryby i skrzypce w powieści Choromańskiego sa raczej beznogimi akcesoriami (a nie bytami), dzięki którym autor sugeruje pogłębiająca się alienację Łasicza, nie zaś wyzwolicielsko spaja jego los z nie-ludzkim światem. Faktyczne wyzwolenie daje bohaterowi Choromańskiego wyłącznie morfina, wszystko inne, co wyświetla się w głowie Łasicza, jest wobec działania morfiny wtórne.

Szpital Czerwonego Krzyża należałoby zatem przeczytać również jako tekst ukazujący okrutne skutki medycznego modelu zdrowia, modelu zakładającego istnienie ściśle określonego szablonu sprawności i ideału ciał i egzystencji. Byłby to kolejny powód - obok nieoczywistych w tej prozie męskich ucieleśnień - dla którego ową z całą pewnością niewybitna, acz intrygująca powieść Michała Choromańskiego trzeba by umieścić na liście lektur istotnych dla polskiej historii „literatury z niepełnosprawnościami” ${ }^{29}$.

\section{BIBLIOGRAFIA}

Brosses Ch. de, O kulcie fetyszów, przeł. M. Skrzypek, Warszawa 1992.

Butler J., Uwikłani w płeć. Feminizm i polityka tożsamości, przeł. K. Krasuska, Warszawa 2008.

Choromański M., Schodami w górę, schodami w dót, Warszawa 2017.

Choromański M., Szpital Czerwonego Krzyża, Poznań 1987.

Galant A., Kobiecość i niepetnosprawność. Między feminizmem a posthumanizmem, [w:] Nowa Kobieta - figury i figuracje, red. I. Iwasiów, A. Krukowska, A. Zawiszewska, Szczecin 2017.

Galant A., Literatura z niepetnosprawnościami. Zarys możliwych lektur, „Czas Kultury” 2019, nr 4.

Garland-Thomson R., Gapienie się, czyli o tym, jak patrzymy i jak pokazujemy siebie innym, przeł. K. Ojrzyńska, „Czas Kultury” 2019, nr 4.

Haraway D., Manifest gatunków stowarzyszonych, przeł. J. Bednarek, [w:] Teorie wywrotowe, red. A. Gajewska, Poznań 2012.

Horkheimer M., Adorno T., Dialektyka oświecenia. Fragmenty filozoficzne, przeł. M. Łukasiewicz, Warszawa 1994.

czająca, w pewnym sensie nawet rewelatorska, gdy mowa o męskości i niepełnosprawności, zarazem jednak pisarz w swojej powieści nie podważa relacji między tym, co ludzkie, a tym, co nie-ludzkie.

${ }^{29}$ Nawiązuję do tekstu A. Galant, Literatura z niepetnosprawnościami. Zarys możliwych lektur, „Czas Kultury” 2019, nr 4. 
Januk J., Terminologia i problematyka medyczna we wczesnych (1931-1939) utworach Michała Choromańskiego, „Medycyna Nowożytna” 2005, 12/1-2.

Kołos S., Od gruźlicy do elektrycznego oka. Medycyna, niepetnosprawność i technologia w Polskiej Kronice Filmowej, „Kultura Współczesna” 2018, nr 3.

Kosińska A., Literatura choromaniaków, „Dekada Literacka” 1997, nr 10-11.

Shusterman R., Świadomość ciała. Dociekania z zakresu somaestetyki, przeł. W. Małecki, S. Stankiewicz, Kraków 2008.

Sobolczyk P., Homogotycki skandal wedtug Choromańskiego, „Czytanie Literatury: Łódzkie Studia Literaturoznawcze" 2014, nr 3.

Śmieja W., Dygresje na temat kampowania męskości. O Dygresjach na temat kaloszy Michała Choromańskiego, [w:] (Nie)męskość w tekstach kultury XIX i XX wieku, red. B. Zwolińska i K.M. Tomala, Gdańsk 2019.

Śmieja W., Erotyzacja relacji męsko-męskich w prozie Michała Chromańskiego, [w:] tegoż, Homoseksualność i polska nowoczesność. Szkice o teorii, historii i literaturze, Katowice 2015.

Umińska B., Michat Choromański. Zazdrość i medycyna, [w:] tejże, Postać z cieniem. Portrety Żydówek w polskiej literaturze, Warszawa 2001.

Wysłouch S., Twórczość Choromańskiego wobec międzywojennego psychologizmu, „Pamiętnik Literacki” 1975, 66/1. 